\title{
French airborne lidar measurements for Eyjafjallajökull ash plume survey
}

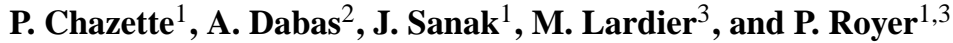 \\ ${ }^{1}$ Laboratoire des Sciences du Climat et de l'Environnement (LSCE), UMR8212, Laboratoire mixte CEA-CNRS-UVSQ, \\ CEA Saclay, 91191 Gif-sur-Yvette, France \\ ${ }^{2}$ Groupe d'Etude de l'Atmosphère Météorologique, URA Météo-France/CNRS, 42 avenue Coriolis, 31100 Toulouse, France \\ ${ }^{3}$ LEOSPHERE, 76 rue de Monceau, 75008 Paris, France
}

Correspondence to: P. Chazette (patrick.chazette@1sce.ipsl.fr)

Received: 28 January 2012 - Published in Atmos. Chem. Phys. Discuss.: 2 March 2012

Revised: 11 July 2012 - Accepted: 12 July 2012 - Published: 6 August 2012

\begin{abstract}
An Ultra-Violet Rayleigh-Mie lidar has been integrated aboard the French research aircraft Falcon20 in order to monitor the ash plume emitted by the Eyjafjallajökul volcano in April-May 2010. Three operational flights were carried out on 21 April, 12 and 16 May 2010 inside French, Spanish and British air spaces, respectively. The original purpose of the flights was to provide the French civil aviation authorities with objective information on the presence and location of the ash plume. The present paper presents the results of detailed analyses elaborated after the volcano crisis. They bear on the structure of the ash clouds and their optical properties such as the extinction coefficient and the lidar ratio. Lidar ratios were measured in the range of 43 to $50 \mathrm{sr}$, in good agreement with the ratios derived from groundbased lidar near Paris (France) in April 2010 ( 48 sr). The ash signature in terms of particulate depolarization was consistent during all flights (between $34 \pm 3 \%$ and $38 \pm 3 \%$ ). Such a value seems to be a good identification parameter for volcanic ash. Using specific cross-sections between 0.19 and $1.1 \mathrm{~m}^{2} \mathrm{~g}^{-1}$, the minimum (maximal) mass concentrations in the ash plumes derived for the flights on 12 and 16 May were 140 (2300) and $250(1500) \mu \mathrm{g} \mathrm{m}^{-3}$, respectively. It may be rather less than, or of the order of the critical level of damage $\left(2 \mathrm{mg} \mathrm{m}^{-3}\right)$ for the aircraft engines, but well above the $200 \mu \mathrm{g} \mathrm{m}^{-3}$ warning level.
\end{abstract}

\section{Introduction}

Due to the winds prevailing in Northern Europe at the time, the ash plume emitted by the Icelandic volcano Eyjafjallajökull (e.g. Sigmundsson et al., 2010) that erupted in AprilMay 2010 was advected from Iceland to the south-east. For several days, it "contaminated" the airspace of Western Europe and lead to a major air traffic disruption (Gertisser, 2010). In France, the "Direction Générale de l'Aviation Civile" (DGAC) and the government authorities closed the airspace entirely from 16 to 21 April 2010, and partially (south-western part of France) from 12 to 16 May 2010.

During these two periods several lidars were operated by various groups throughout Europe with the purpose of increasing knowledge on ash properties and assess their potential danger to aviation. Ansmann et al. (2011) proposed an original approach coupling lidar and sunphotometer to retrieve the content of ash over central Europe using the existent networks AERONET and EARLINET. The coupling between ground-based remote sensors including lidar was also proposed by Gasteiger et al. (2011) to constrain the ash size distribution. Another original work was conducted by Chazette et al. (2012) using the coupling between lidar (ground-based and spaceborne systems), sunphotometer and numerical model to retrieve the ash optical properties over the Paris area and the assessment of the ash mass concentration. The ash plume was also analyzed with active (e.g. Chazette et al., 2012) and passive (e.g. Millington et al., 2012) spaceborne sensors. This last approach followed the work of Prata et al. (2010) and Thomas and 
Watson (2010) by using multispectral remote-sensing observations from satellites to characterize volcanic emission from space. During the Eyjafjallajökull crisis, airborne measurements also played a major role for the retrieval of microphysical ash properties by analyzing air samples captured during the flights (Schumann et al., 2011; Johnson et al., 2011; Bukowiecki et al., 2011) and using lidar measurements (e.g. Marenco et al., 2011).

The use of lidar measurements to characterize volcanic aerosols is not new. Following the major eruptions of $\mathrm{El}$ Chichon in 1982 and Mount Pinatubo in 1991, volcanic plumes were extensively studied in the stratosphere by both ground-based and airborne lidars. For instance, Jäger (1992) used a lidar at Garmisch-Partenkirchen (Germany) to investigate the volcanic aerosol in the stratosphere following the Mount Pinatubo eruption. Simultaneously, lidar measurements were performed at Hampton (Virginia, USA) by Osborn et al. (1995). In France, Chazette et al. (1995) used lidar observations from the "Observatoire de Haute Provence" (OHP) to characterize the aerosol plume in the stratosphere following the eruptions of El Chichon and Mount Pinatubo. The residence time of volcanic aerosols was thus assessed. The ash plume of Mount Pinatubo was also investigated with an airborne lidar by Winker et al. (1992). The chemical nature of volcanic aerosol is likely to be different in the troposphere than in the stratosphere. Following a major eruption, the precursor of the aerosols in the stratosphere is the dioxide sulfide $\left(\mathrm{SO}_{2}\right)$ leading to the creation of sulfuric acid in aqueous solution (Rosen and Hofmann, 1986) whereas it is a mixing of ash and sulfate in the troposphere (Schumann et al., 2011). In the recent past, some authors used lidars from ground to characterize the volcanic aerosol following the eruptions of Etna (Pappalardo et al., 2004; Wang et al., 2008) or Augustine in 2006 (Sassen et al., 2007), and the contribution to the troposphere of different volcanoes over Europe (Mattis et al., 2010).

In this paper we present the contribution of the sole French airborne lidar (AL) that flew during the international airline crisis caused by the Eyjafjallajökul eruption. The AL was built from an ALS450 manufactured by the Leosphere Compagny and was initially developed at the "Laboratoire des Sciences du Climat et de l'Environnement" (LSCE). A similar system has already flown aboard an ultra-light aircraft during the African Monsoon Multidisciplinary Analyses (AMMA) (e.g. Chazette et al., 2007), as well as aboard the FAAM BAe-146 research aircraft (www.faam.ac.uk) (e.g. Marenco et al., 2011). The lidar is briefly presented in Sect. 2 where we also remind how aerosol optical properties can be derived from the co-polar and cross-polar channels of a lidar. The flight plans are presented in Sect. 3 with the identification of the ash plume from the cross-polar channel. In Sect. 4, the ash plume optical properties retrieved from the lidar profiles are presented with their uncertainties and we propose an estimation of the ash mass concentration us-
Table 1. Main characteristic of the airborne lidar system.

\begin{tabular}{ll}
\hline Characteristics & Details \\
\hline Lidar head size & $\sim 65 \times 35 \times 18 \mathrm{~cm}$ \\
Lidar head and electronic weight & $\sim 40 \mathrm{~kg}$ \\
Laser type & Nd:YAG 20Hz $16 \mathrm{~mJ} @ 355 \mathrm{~nm}$ \\
Laser pulse length & $\sim 5-7 \mathrm{~ns}$ \\
Laser divergence & $0.1 \mathrm{mrad}$ \\
Reception channels & Elastic $355 \mathrm{~nm} / /$ et $\perp$ \\
Reception diameter & $150 \mathrm{~mm}$ \\
Field of view & $\sim 2.3 \mathrm{mrad}$ \\
Full-overlap & $200 \mathrm{~m}$ \\
Detector & Photomultiplier (analog mode) \\
Filter bandwidth & $0.3 \mathrm{~nm}$ \\
Electronic system & PXI $100 \mathrm{MHz}$ \\
Vertical sampling (resolution) & $1.5 \mathrm{~m}(15 \mathrm{~m})$ \\
\hline
\end{tabular}

ing the previous results published in the scientific literature. Section 5 summarizes the findings.

\section{The airborne lidar}

The AL was flown aboard the Falcon 20 (F-20) of the "Service des Avions Français Instrumentés pour la Recherche en Environnement" (SAFIRE, see www.safire.fr) which operates several aircrafts for research purposes in the environment domain. SAFIRE Falcon 20 is an original Dassault Falcon 20 GF specially modified for scientific uses. Its usual cruising speed is $150 \mathrm{~m} \mathrm{~s}^{-1}$ and its endurance is close to $5 \mathrm{~h}$ (maximal flight range $\sim 4100 \mathrm{~km}$ ) depending on the scientific payload (usually $\sim 1200 \mathrm{~kg}$ ). Its maximum flight ceiling is $\sim 42000 \mathrm{ft}(12000 \mathrm{~m})$.

\subsection{Technical characteristics of the AL}

The AL has been built at LSCE following the precursor instrument LAUVA (Lidar Aérosol UltraViolet Aéroporté, Chazette et al., 2007; Raut and Chazette, 2009). It could be considered as a home-made alternative version of the ALS450 manufactured by the LEOSPHERE compagny (www.leosphere.com). It emits in the ultraviolet $(355 \mathrm{~nm})$, and is based on a $20 \mathrm{~Hz}$ pulsed Nd:YAG laser (ULTRA) manufactured by QUANTEL (www.quantel.com). The acquisition system is based on a PXI (PCI eXtensions for Instrumentation) technology. Its main characteristics are summarized in Table 1. The UV pulse energy is $16 \mathrm{~mJ}$ and the pulse repetition rate is $20 \mathrm{~Hz}$. The receiver implements two channels for the detection of the elastic backscatter from the atmosphere in the parallel and perpendicular polarization planes relative to the linear polarization of the emitted radiation. It was designed to monitor the aerosol distribution and dispersion in the low and middle troposphere. It enables the retrieval of aerosol optical properties (extinction, backscatter coefficient and depolarization ratio) and atmospheric structures like the planetary boundary layer (PBL), aerosol layers and clouds, 
with a line of sight resolution close to $15 \mathrm{~m}$. With a $15 \mathrm{~cm}$ diameter telescope, the lidar is compact $(\sim 70 \times 45 \times 18 \mathrm{~cm})$ and lightweight $(<50 \mathrm{~kg}$ for both optics and electronics) and can thus be easily mounted aboard an aircraft. The wide field-ofview $(\mathrm{FOV}) \sim 2.3 \mathrm{mrad}$ ensures a full-overlap of the transmit and receive paths beyond $\sim 200 \mathrm{~m}$.

\subsection{The lidar signal}

Assuming a perfect separation of the 2 polarizations, the range corrected lidar signals $S^{1(2)}$ at the emitted wavelength $\lambda$ for both the co-polarization (//, channel 1$)$ and the crosspolarization $(\perp$, channel 2$)$ channels is given as a function of range $r$ by (Measures, 1984)

$$
\begin{aligned}
S^{1(2)}(r) & =C^{1(2)} \cdot\left(\beta_{\mathrm{m}}^{1(2)}(r)+\beta_{\mathrm{a}}^{1(2)}(r)\right) \\
& \cdot \exp \left(-2 \cdot \int_{0}^{r}\left(\alpha_{\mathrm{m}}\left(r^{\prime}\right)+\alpha_{\mathrm{a}}\left(r^{\prime}\right)\right) \cdot \mathrm{d} r^{\prime}\right)
\end{aligned}
$$

The molecular (resp. aerosol) contribution is characterized by both the extinction $\alpha_{\mathrm{m}}$ (resp. $\alpha_{\mathrm{a}}$ ) and the backscatter coefficients $\beta_{\mathrm{m}}^{1(2)}$ (resp. $\beta_{\mathrm{a}}^{1(2)}$ ). The molecular extinction and backscatter coefficients are known functions of the air density and can thus be predicted with a good accuracy from either a climatological profile of air density, or more precisely from a weather analysis or a radio-sounding by a polynomial approximation as proposed by Nicolet (1984). $C^{1(2)}$ are the instrumental constants for each channel.

Taking into account that the two Brewster plates used for the separation of the two polarizations are not perfect (Fig. 1), the total elastic lidar signal must be computed from the two polarized signals by using the equation

$$
S(r)=\frac{S^{1}(r) \cdot(1+\operatorname{VDR}(r))}{C^{1} \cdot\left(T_{1}^{/ /}+T_{1}^{\perp} \cdot \operatorname{VDR}(r)\right)}
$$

where VDR is the volume depolarization ratio

$$
\operatorname{VDR}(r)=\frac{R_{\mathrm{c}} \cdot\left(1-T_{1}^{/ /}\right) \cdot\left(1-T_{2}^{/ /}\right) \cdot S^{1}(r)-T_{1}^{/ /} \cdot S^{2}(r)}{T_{1}^{\perp} \cdot S^{2}(r)-R_{\mathrm{c}} \cdot\left(1-T_{1}^{\perp}\right) \cdot\left(1-T_{2}^{\perp}\right) \cdot S^{1}(r)}
$$

$T_{i}^{/ /}$and $T_{i}^{\perp}$ are the transmissions of the co-polarization and cross-polarization contributions of the Brewster plate $i$, respectively. The cross-calibration coefficient $R_{\mathrm{c}}=C^{2} / C^{1}$ can be assessed by normalizing at the lidar signals obtained in a "clean" atmospheric volume with negligible aerosol content:

$$
R_{\mathrm{c}}=\frac{S^{2}\left(r_{\mathrm{m}}\right) \cdot\left(T_{1}^{/ /}+\mathrm{VDR}_{\mathrm{m}} \cdot T_{1}^{\perp}\right)}{S^{1}\left(r_{\mathrm{m}}\right)\left[\left(1-T_{1}^{/ /}\right) \cdot\left(1-T_{2}^{/ /}\right)+\mathrm{VDR}_{\mathrm{m}} \cdot\left(1-T_{1}^{\perp}\right) \cdot\left(1-T_{2}^{\perp}\right)\right]}
$$

where the molecular volume depolarization ratio $\left(\mathrm{VDR}_{\mathrm{m}}\right)$ was taken equal to $0.3945 \%$ at $355 \mathrm{~nm}$ following Collis and Russel (1976). There, the lidar signal is due solely to

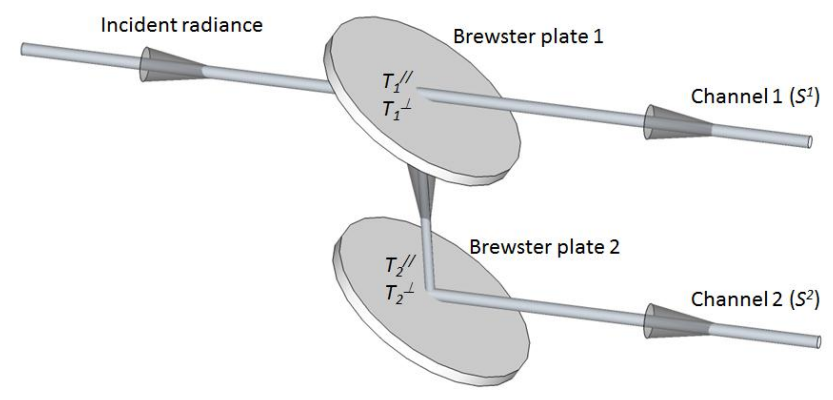

Fig. 1. Schematic representation of the co-polar and cross-polar channels.

the known molecular backscatter for the altitude $z_{\mathrm{m}}\left(z_{\mathrm{m}}=\right.$ $z_{\mathrm{f}}-r_{\mathrm{m}}$, where $z_{\mathrm{f}}$ is the flight altitude) between 6 and $7 \mathrm{~km}$ above the mean sea level (a.m.s.l.). Note that because of the narrow width of the interferential filter $(0.3 \mathrm{~nm})$ of the receiver, only Cabannes scattering is observed by the lidar. The mean relative uncertainty on the cross-calibration coefficient was assessed before the flights over the Paris area and compared to the one of another ground-based lidar (GBL) used to follow the ash plume (Chazette et al., 2012). These measurements performed from ground for the two lidars during the night of 19 April 2010 (23:00 LT) are shown in Fig. 2. The vertical profiles of apparent backscatter coefficient $\beta_{\text {app }}^{/ /(\perp)}\left(S^{1(2)}\right.$ corrected from the molecular transmission) derived from the two lidars are in very good agreement.

The previous equations assume that the laser is fully polarized at the emission and no rotation exists between the polarization planes of the emission and reception. The laser residual perpendicular polarization has been assessed on an optical bench in the laboratory. It was found to be close to $2.0 \%$ ( 2 per mil). Moreover, we performed measurements with and without a Glan-prism placed at the exit of the laser and we have not observed significant differences on the depolarization ratio. The emission and reception paths are on the same integration plate to ensure that emission and reception optical axes are parallel. The orientations of the two Brewster plates are adjusted so as to maximize the backscatter signal on each channel. Moreover, the supports of the Brewster plates are machined at $56 \pm 2^{\circ}$, the residual tolerance is for adjustment in the laboratory. To evaluate the uncertainty on the Brewster angular position we have repeated the measurement 4 times on an optical bench. The standard deviation has been assessed to be $0.3 \%$. Hence, the dominant error source is indeed the characterization of the plate transmission.

The Brewster plates of the GBL were characterized at the LSCE on an optical bench. We found $T_{1,2}^{/ /}=0.92, T_{1}^{\perp}=$ 0.0012 and $T_{2}^{\perp}=0.0009$ with a relative uncertainty of $1 \%$ and $35 \%$ for the parallel and perpendicular channels, respectively. The polarization of the AL has been calibrated by comparison to the GBL and its Brewster plate transmissions 

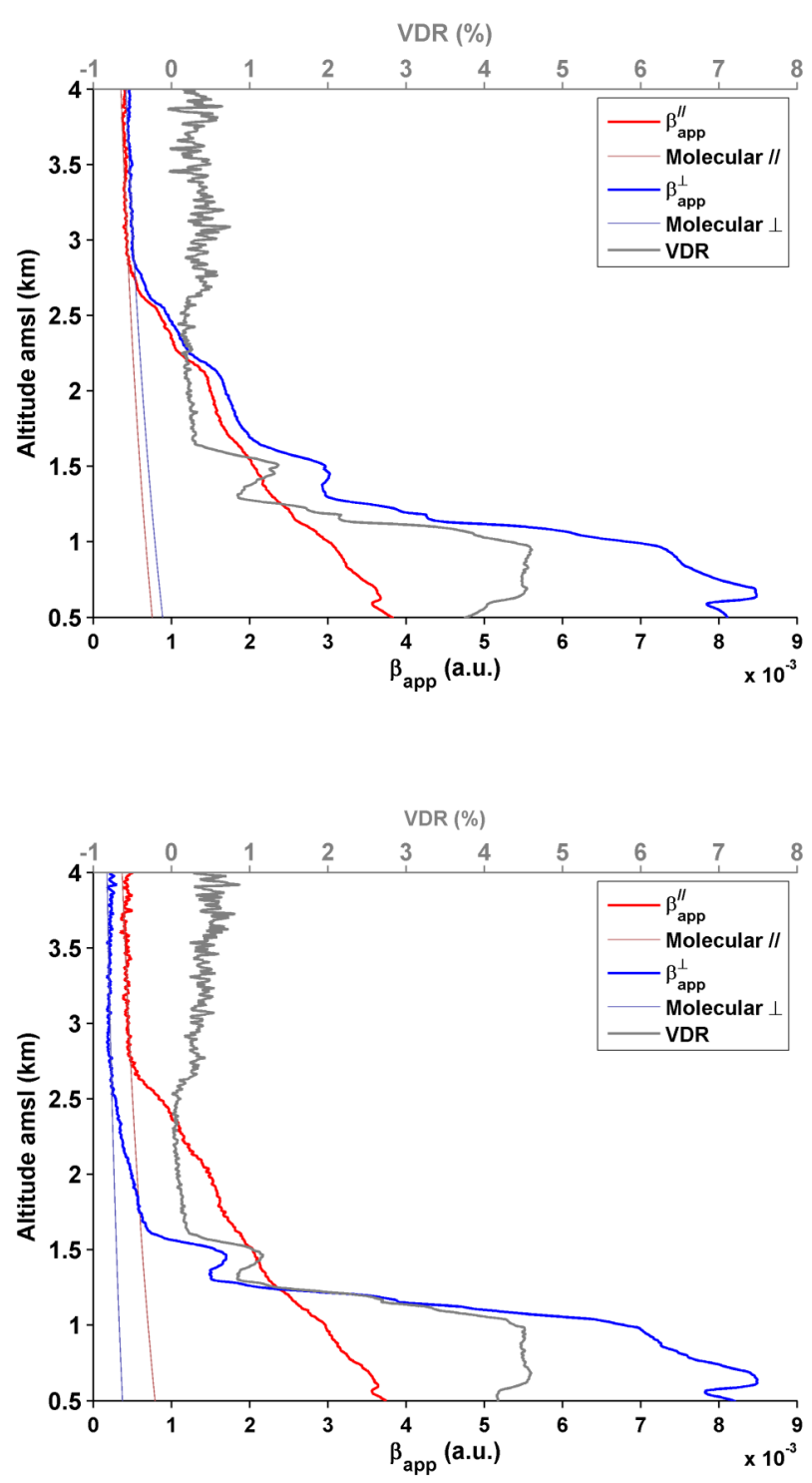

Fig. 2. Vertical profiles of the apparent backscatter coefficient $\beta_{\text {app }}^{/ /(\perp)}$ and VDR for the AL (top) and GBL (bottom). The molecular contribution is also indicated for the co-polar and cross-polar channels.

were found to be $T_{1,2}^{/ /}=0.805, T_{1}^{\perp}=0.0007$ and $T_{2}^{\perp}=$ 0.0009 . The VDR retrieved from the AL and GBL match within $1 \%$, and the relative error on $T_{1.2}^{/ /}$for the $\mathrm{AL}$ can be considered to be less than $1.5 \%$. Considering that the perpendicular transmissions are very low, Eqs. (2), (3) and (4) can be simplified

$S(r) \approx \frac{S^{1}(r) \cdot(1+\mathrm{VDR}(r))}{C^{1} \cdot T_{1}^{/ /}}$

$\operatorname{VDR}(r) \approx \frac{T_{1}^{/ /} \cdot S^{2}(r)}{R_{\mathrm{c}} \cdot S^{1}(r)}-\left(1-T_{1}^{/ /}\right) \cdot\left(1-T_{2}^{/ /}\right)$.

$$
R_{\mathrm{c}} \approx \frac{S^{2}(r \mathrm{~m}) \cdot T_{1}^{/ /}}{S^{1}(r \mathrm{~m})\left[\left(1-T_{1}^{/ /}\right) \cdot\left(1-T_{2}^{/ /}\right)+\mathrm{VDR}_{\mathrm{m}}\right]}
$$

Hence, the previous variables are functions of $K=$ $\left(1-T_{1}^{/ /}\right) \cdot\left(1-T_{2}^{/ /}\right)$which is a measure of how the lidar system is affected by imperfect separation of polarizations. The values of $K$ are 0.038 and 0.0064 for the $\mathrm{Al}$ and GBL, respectively. For the AL, the laser residual cross-polarization of 0.002 can be neglected, but it is not the case for the GBL where it represents $\sim 30 \%$ of the imperfect separation of polarizations.

The value of $R_{\mathrm{c}}$ may vary with the temperature. We investigated this aspect by varying the temperature of the optical room from 18 and $25^{\circ} \mathrm{C}$ (range of temperatures likely to be found in the Falcon). No significant impact was observed on $R_{\mathrm{c}}$. Our system was found to be stable with varying temperature and for different flights (see Table 2). This is in contrast with what Marenco et al. (2011) observed on their Leosphere lidar, where temperature variations prevented exploiting the depolarized signal and it suggests that each individual instrument is different and needs a tailored characterization and tuning. Nevertheless, $R_{\mathrm{c}}$ is a function of the optical densities (ODs) placed in each channel, it is proportional to the transmission of the ODs. For airborne operations, the optical densities of the AL were adjusted so as to optimize the signal to noise ratio and avoid the saturation of detectors. At ground, $R_{\mathrm{c}}=22.6 \pm 0.7$ but this value evolved when the lidar was flying to $9.1 \pm 0.2$ on 21 April 2010 to $15.7 \pm 0.2$ and $15.2 \pm 0.4$ on 12 and 16 May 2010, respectively. The \pm given on the $R_{\mathrm{c}}$ value characterizes its variability on different altitudes where only molecular scattering occurs. Between the last two flights $R_{\mathrm{c}}$ was very stable because no change have been done on the lidar whereas an adaptation of the ODs was made after the first flight.

\subsection{Retrieval of the ash plume optical properties}

The retrieval of the ash optical properties from the AL is performed in two steps. In the first step, the aerosol optical thickness (AOT) of the ash layer plume is assessed (if possible). The second step consists of the inversion of the lidar equation. As it is well known, the inversion of lidar equations is an ill-posed problem as it contains two unknowns for a single equation. An additional constraint is thus needed. For an airborne lidar, such a constraint can be found when the aerosol plume is boarded by two atmospheric layers where only molecular scattering occurs. This specific situation has been encountered during our flights. Then the ash AOT can be easily written as

$$
\begin{aligned}
& \mathrm{AOT}=\int_{z_{\mathrm{b}}}^{z_{\mathrm{a}}} \alpha_{\mathrm{a}}(z) \cdot \mathrm{d} z \\
& \mathrm{AOT}=\frac{1}{2} \cdot \operatorname{Ln}\left(\frac{\beta_{\mathrm{m}}\left(z_{\mathrm{a}}\right)}{\beta_{\mathrm{m}}\left(z_{\mathrm{b}}\right)} \cdot \frac{S\left(z_{\mathrm{b}}\right)}{S\left(z_{\mathrm{a}}\right)}\right)-\int_{z_{\mathrm{b}}}^{z_{\mathrm{a}}} \alpha_{\mathrm{m}}(z) \cdot \mathrm{d} z
\end{aligned} .
$$


Table 2. Optical properties of the ash plumes. The relative statistic uncertainties $\left(\varepsilon_{x}\right)$ are given for each property $x$ and plume type. They have been calculated for the main sources of standard deviation: the signal noise and the Brewster plate transmissions $\left(T_{1,2}^{/ /}\right)$.

\begin{tabular}{|c|c|c|c|c|c|}
\hline & & $16 / 05$ & 12/05 Plume & 12/05 Plume-crown & 12/05 Filament \\
\hline \multicolumn{6}{|c|}{ Uncertainties linked to the shot noise } \\
\hline \multirow{13}{*}{$\begin{array}{l}R\left(z_{\mathrm{a}}\right)=1 \\
R\left(z_{\mathrm{b}}\right)=1\end{array}$} & $\mathrm{SNR}_{\mathrm{b}}$ & 12 & 12 & 19 & 14 \\
\hline & $\mathrm{SNR}_{\mathrm{a}}$ & 35 & 28 & 56 & 27 \\
\hline & $R_{\mathrm{c}}$ & $15.2 \pm 0.4$ & $15.7 \pm 0.2$ & $15.7 \pm 0.2$ & $15.7 \pm 0.2$ \\
\hline & VDR & $0.12 \pm 0.04$ & $0.11 \pm 0.01$ & $0.09 \pm 0.01$ & $0.16 \pm 0.06$ \\
\hline & AOT & 0.34 & 0.19 & 0.08 & 0.17 \\
\hline & BER & $0.021 \mathrm{sr}^{-1}$ & $0.023 \mathrm{sr}^{-1}$ & $0.020 \mathrm{sr}^{-1}$ & $0.027 \mathrm{sr}^{-1}$ \\
\hline & PDR & $0.38 \pm 0.03$ & $0.38 \pm 0.04$ & $0.34 \pm 0.03$ & $0.36 \pm 0.04$ \\
\hline & $\max \left(\alpha_{\mathrm{a}}\right)$ & $0.28 \mathrm{~km}^{-1}$ & $0.41 \mathrm{~km}^{-1}$ & $0.15 \mathrm{~km}^{-1}$ & $0.44 \mathrm{~km}^{-1}$ \\
\hline & $\varepsilon_{\mathrm{VDR}}$ & $1 \%$ & $1 \%$ & $1 \%$ & $1 \%$ \\
\hline & $\varepsilon_{\mathrm{AOT}}$ & $2 \%$ & $2 \%$ & $4 \%$ & $2 \%$ \\
\hline & $\varepsilon_{\mathrm{BER}}$ & $2 \%$ & $2 \%$ & $5 \%$ & $2 \%$ \\
\hline & $\varepsilon$ PDR & $1 \%$ & $1 \%$ & $1 \%$ & $2 \%$ \\
\hline & $\varepsilon_{\alpha}$ & $3 \%$ & $2 \%$ & $6 \%$ & $2 \%$ \\
\hline \multicolumn{6}{|c|}{ Uncertainties linked to the Brewster plate transmissions } \\
\hline \multirow{6}{*}{$\frac{\sigma_{T_{1,2}^{/ /}}}{T_{1,2}^{/ /}} \approx 1.5 \%$} & $\varepsilon_{\mathrm{Rc}}$ & $9 \%$ & $6 \%$ & $12 \%$ & $9 \%$ \\
\hline & $\varepsilon \mathrm{VDR}$ & $8 \%$ & $6 \%$ & $10 \%$ & $9 \%$ \\
\hline & $\varepsilon_{\mathrm{AOT}}$ & $0.1 \%$ & $0.1 \%$ & $0.3 \%$ & $0.3 \%$ \\
\hline & $\varepsilon_{\mathrm{BER}}$ & $2 \%$ & $2 \%$ & $3 \%$ & $2 \%$ \\
\hline & $\varepsilon$ PDR & $9 \%$ & $10 \%$ & $24 \%$ & $12 \%$ \\
\hline & $\varepsilon_{\alpha}$ & $0.2 \%$ & $0.2 \%$ & $0.3 \%$ & $0.2 \%$ \\
\hline
\end{tabular}

where $z$ is the altitude $\operatorname{amsl}\left(z=z_{\mathrm{f}}-r \cos (\theta)\right.$ with $z_{\mathrm{f}}$ the aircraft altitude and $\theta$ the pointing angle relative to nadir); $z_{\mathrm{b}}$ and $z_{\mathrm{a}}$ are the altitudes within the molecular layers beneath and above the ash plume, respectively. Using the backscatter to extinction ratio (BER, inverse of the lidar ratio LR), the elastic Eq. (1) becomes a differential equation of type Bernoulli first order and can be mathematically inverted (Klett, 1985)

$$
\begin{aligned}
& \underbrace{\left(\frac{S(z) Q(z)}{\frac{S\left(z_{\mathrm{a}}\right)}{\left(\beta_{\mathrm{m}}\left(z_{\mathrm{a}}\right)+\beta_{\mathrm{a}}\left(z_{\mathrm{a}}\right)\right)}-2 \cdot \mathrm{BER}^{-1} \int_{z}^{z_{\mathrm{a}}} S\left(z^{\prime}\right) Q\left(z^{\prime}\right) \mathrm{d} z^{\prime}}-\beta_{\mathrm{m}}(z)\right)}_{\beta_{\mathrm{a}}(z)}
\end{aligned}
$$

Here, $Q$ is the correction factor related to the differential molecular optical thickness calculated from the vertical profile of the molecular scattering coefficient as

$$
Q(z)=\exp \left(2\left[1-k_{\mathrm{f}} \frac{3}{8 \pi \cdot \mathrm{BER}}\right] \int_{z}^{z_{\mathrm{a}}} \alpha_{\mathrm{m}}\left(z^{\prime}\right) \mathrm{d} z^{\prime}\right)
$$

where $k_{\mathrm{f}}$ is the King factor of air (King, 1923). Considering $k_{\mathrm{f}}=1$ leads to an overestimation on the molecular volume backscatter coefficient of only $1.5 \%$ at $355 \mathrm{~nm}$ (Collis and Russel, 1976). BER is assessed using the AOT as a constraint in Eq. (9) via a dichotomy approach as described by
Chazette (2003) or Royer et al. (2011). As shown in Berthier et al. (2006), the BER is overestimated when multiple scattering occurs. With a field of view of $2.3 \mathrm{mrad}$ and a flight at $10 \mathrm{~km}$ a.m.s.l., we have assessed a relative uncertainty of $1 \%$ on the BER, which has been hereafter neglected in comparison to the other sources of uncertainty. The value hence retrieved is constant for the entire ash layer. This assumes that the ash are distributed homogeneously across the plume.

The uncertainties in the determination of AOT, $\alpha_{\mathrm{a}}$ and BER can be related to three main sources: (i) the detection noise (shot noise, electronic noise...), (ii) the presence of residual aerosols in the altitude ranges used for lidar calibration, (iii) the uncertainty on the a priori knowledge of the vertical profile of the Rayleigh backscatter coefficient as determined from ancillary measurements. This last uncertainty is negligible $\left(<2 \%\right.$ on $\alpha_{\mathrm{a}}$ or BER) compared to the others. The statistical uncertainties on the ash optical parameters have been calculated (see Sect. 4.1) using a Monte Carlo approach as in Chazette (2003).

The higher contribution of the molecular scattering at $355 \mathrm{~nm}$ leads to prefer the particulate depolarization ratio (PDR) to characterize the ash depolarization properties linked to their non-sphericity. The PDR is given by (Chazette et al., 2012) 
$\operatorname{PDR}(z)=$

$$
\frac{\beta_{\mathrm{m}}(z) \cdot\left(\mathrm{VDR}_{\mathrm{m}}-\operatorname{VDR}(z)\right)-\beta_{\mathrm{a}}(z) \cdot \operatorname{VDR}(z) \cdot\left(1+\mathrm{VDR}_{\mathrm{m}}\right)}{\beta_{\mathrm{m}}(z) \cdot\left(\operatorname{VDR}(z)-\mathrm{VDR}_{\mathrm{m}}\right)-\beta_{\mathrm{a}}(z) \cdot\left(1+\mathrm{VDR}_{\mathrm{m}}\right)}
$$

The PDR is generally very noisy because it is the ratio of two noisy functions of $\beta_{\mathrm{a}}$. Hence, its assessment is restricted to high values of aerosol extinction coefficient $\left(>0.1 \mathrm{~km}^{-1}\right.$ for our AL).

\section{Flights plans and ash plume identification}

Probable presence of volcanic ash was detected during three flights of the F-20. These flights were carried out on 21 April, 12 and 16 May 2010, inside the French, Spanish and British air spaces, respectively. The aircraft took off from the military airport of Toulouse-Francazal for each of them, and landed on the same airport. The volcanic ash plume has been mainly identified using the perpendicular channel of the airborne lidar, in terms of $\beta_{\text {app }}^{\perp}$.

On 21 April 2010, while air traffic was resuming over France, a thin volcanic aerosol layer was measured in the Northern part of France above a cloud layer between Strasbourg and Dieppe (Fig. 3). The AOT of the ash plume was lower than 0.03 at $355 \mathrm{~nm}$ (retrieved from ground-based lidar, not shown). It is thus very difficult to retrieve the ash optical properties from an airborne lidar. Moreover, there is no molecular layer beneath the ash plume. Hereafter, we do not consider these lidar measurements for a quantitative study. Note that the PBL signature on Fig. 3 appears similar to the one of the ash plume but is mainly due to dust-like trapped in the thermal convection.

The second flight occurring on 12 May was over the Atlantic Ocean, off the Spanish coast (La Coruna), towards the West as shown Fig. 4. A filament $(\sim 500 \mathrm{~m}$ deep $)$ with a high lidar signal was first observed by the AL (located between -9.82 and $-12.06^{\circ}$ in longitude and at $\sim 5 \mathrm{~km}$ a.m.s.l. in Fig. 4). But the main body of the volcanic plume was found further west at about the limit of range of the aircraft ( $\sim 1200 \mathrm{~km}$ off La Coruna). Therefore only the edge of the plume could be observed by the AL. It extends vertically from 2 to $\sim 7 \mathrm{~km}$ a.m.s.l. Lidar signals are reported in Fig. 4. The figure is nearly symmetrical as the aircraft flew a return flight along almost the same route. The backtrajectories computed with the HYSPLIT (Hybrid Single Particle Lagrangian Integrated Trajectory Model) model (courtesy of NOAA Air Resources Laboratory; http://www.arl.noaa.gov) are shown in Fig. 5. The ash that were present within the filament and the plume were not emitted on the same day (10 May for the filament and 11 May for the plume) neither advected with the same efficiency. For the filament, the main contribution to the lidar signal came from an altitude of $\sim 2 \mathrm{~km}$ a.m.s.l., whereas it came between 4 and $5 \mathrm{~km}$ a.m.s.l. for the main plume.
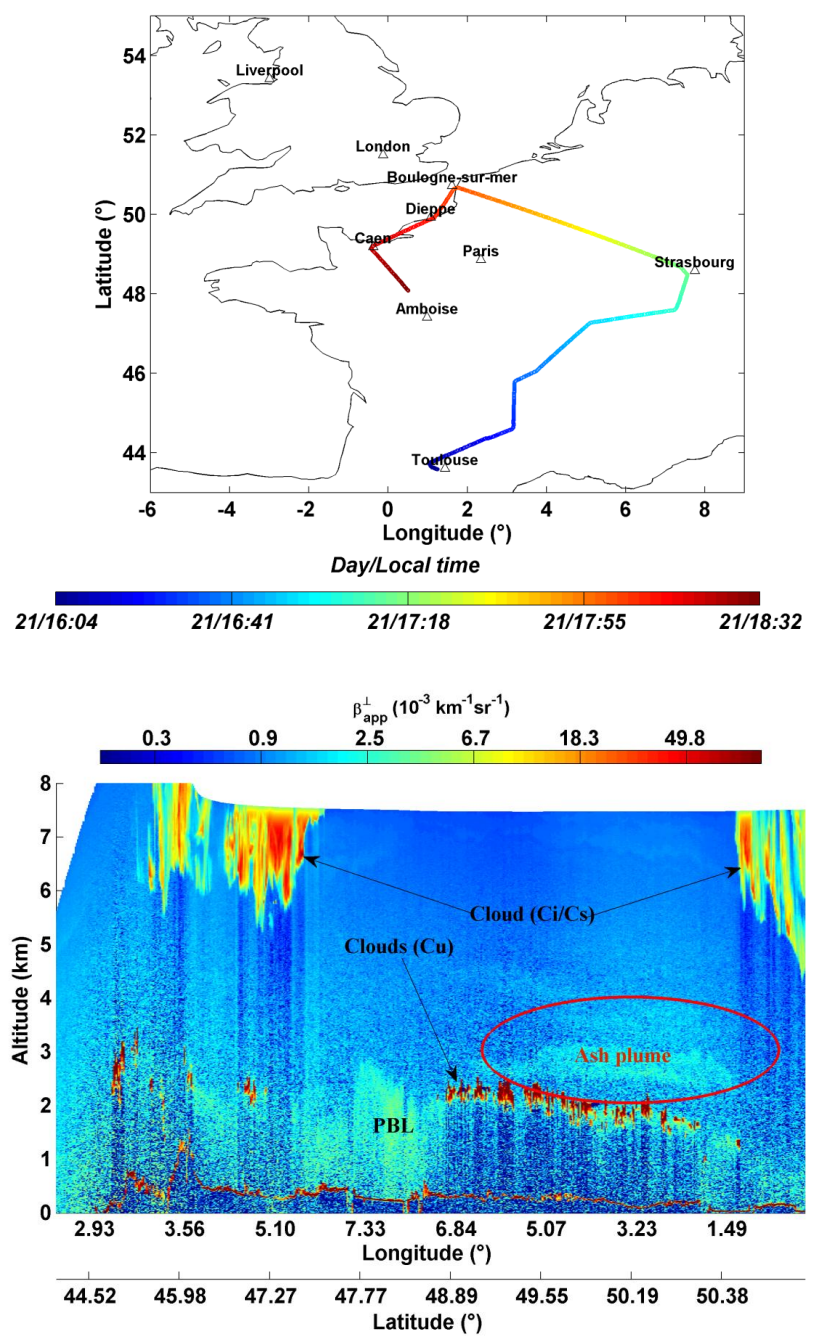

Fig. 3. Flight for 21 April 2010. Top panel shows the flight plane above France where the main crossed cities are given. Bottom panel shows the temporal evolution of $\beta_{\text {app }}^{\perp}$. The shallow ash plume is circled in red.

On 16 May, the British air space was closed. Volcanic ash were expected and encountered in the North of England. The ash plume is well located by the AL measurements as shown Fig. 6 . It lies between $\sim 3$ and $6 \mathrm{~km}$ a.m.s.l. Backtrajectories from different end-points within the ash plume are displayed in Fig. 7. They confirm the source of the ash plume as being the Eyjafjallajökull volcano.

Note that the ubiquitous cloud cover during the flights makes it difficult to identify ash plumes from space. Few cloud-free pixels are available on SEVERI or MODIS (not shown) and backtrajectories appear as the most relevant means to identify the origin of the ash layers detected from the AL. 

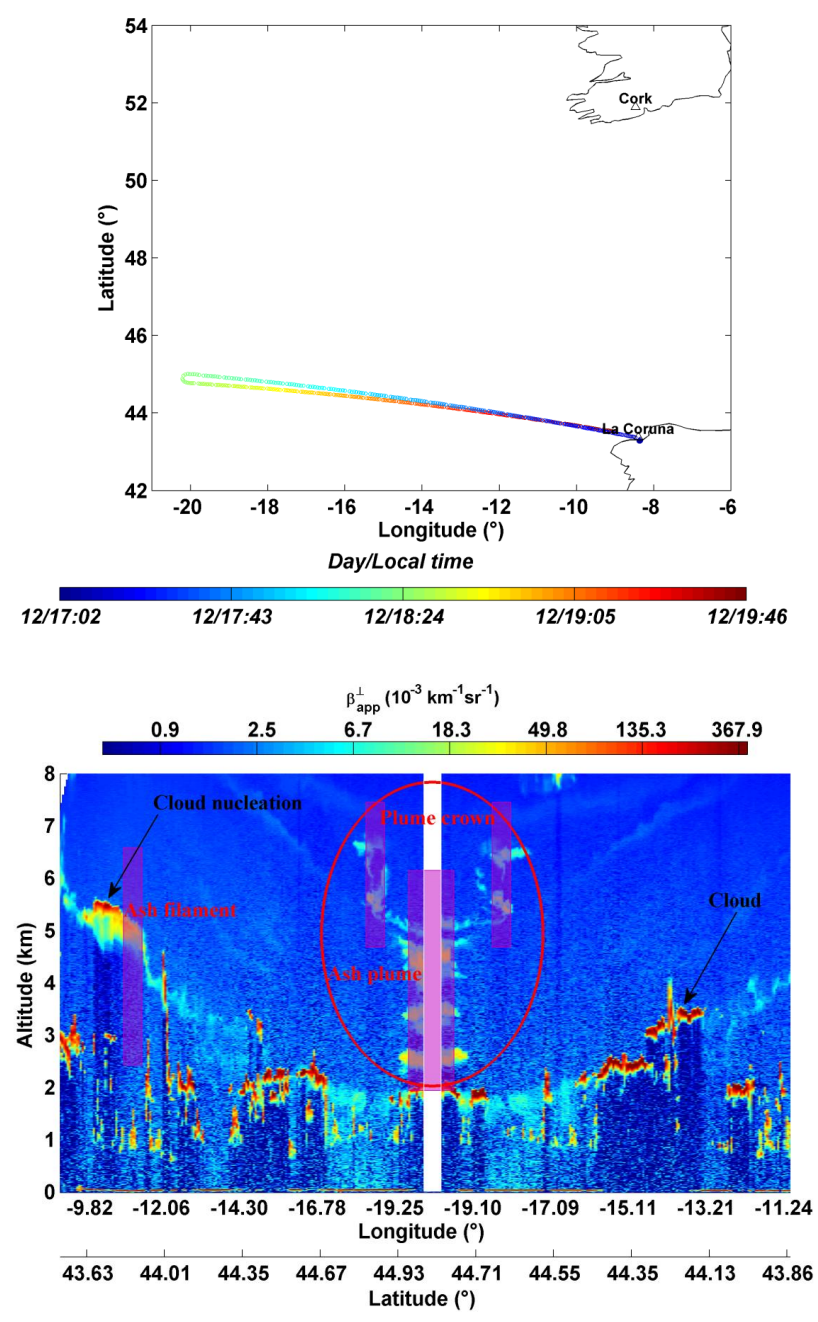

Fig. 4. The same as Fig. 3 for 12 May 2010, off La Coruna. The areas where the mean lidar profiles have been studied are highlighted by purple rectangles.

\section{Optical properties and mean ash mass concentration}

The calculations were performed on mean profiles measured in the ash plumes for which we have two molecular normalization points, above and beneath the plume $\left(z_{\mathrm{a}}\right.$ and $z_{\mathrm{b}}$, respectively). The locations of the mean profiles are highlighted on Figs. 4 and 6 for 12 and 16 May, respectively. The averaging of lidar signals was done in order to improve the signal to noise ratio (SNR) in the molecular zones so that it exceeds 10 needed for an accurate inversion (Table 2). The assessment of the ash optical properties does not require assumptions about the chemical nature and morphological properties of the ash. This is not the case for the assessment of the ash mass concentrations (e.g. Gasteiger et al., 2011; Chazette et al., 2012).

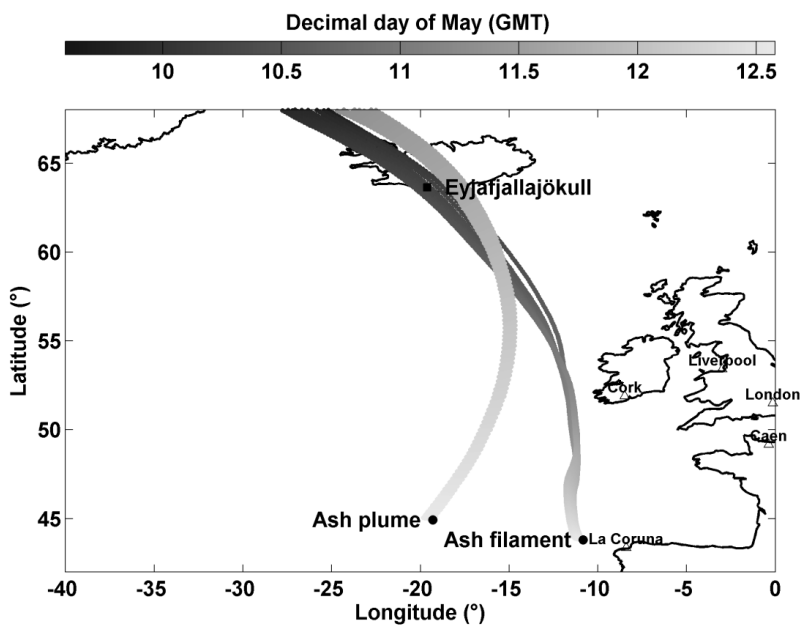

Fig. 5. Backtrajectories on 12 May 2010 computed using the Hysplit model (courtesy of NOAA Air Resources Laboratory; http: //www.arl.noaa.gov). The wind fields are from GDAS (Global Data Assimilation System, http://www.ncep.noaa.gov/) at the horizontal resolution of $1^{\circ}$. Two terminal locations of the air masses are considered: one in the ash plume and the other one in the filament. All the lidar observations in the ash structures are considered as the individual final location of the air masses.

\subsection{Optical parameters}

The range-corrected mean lidar signal is given in Fig. 8 for 12 and 16 May 2010. For 12 May, we have firstly distinguished the plume from the filament, and secondly we have considered separately the plume-crown, located between $\sim 5$ and $7 \mathrm{~km}$ a.m.s.l., from the plume itself, which is located below, between $\sim 2$ and $5 \mathrm{~km}$ a.m.s.l. (Fig. 5). Note that the lower molecular reference altitude is above a cloud layer. Moreover, the higher and lower molecular references $z_{\mathrm{a}}$ and $z_{\mathrm{b}}$ are very likely to be contaminated by residual aerosol contribution and the AOTs are likely biased. It is unclear whether aerosols are a priori present at the molecular reference level. Hence, the potential bias on the optical parameters was assessed using one (two) scattering coefficient(s) $\left(R=1+\beta_{\mathrm{a}} / \beta_{\mathrm{m}}\right)$ at the higher (lower) molecular reference altitude(s). At the molecular reference $z_{\mathrm{b}}, R=1.05$ (1.09) leads to a bias on the lidar signal at least equal to the (twice) signal noise level. Such a deviation is assumed to be observable on the profiles of Fig. 8. The uncertainties linked to the Brewster plate transmission have been also assessed on each optical parameter using a Monte Carlo approach (Chazette et al., 2001). The results are summarized in Tables 2, 3 and 4. For the total error budget given in Table 4, we have considered that a deviation from molecular scattering with $R=1.02$ (1.05) is identifiable at the higher (lower) molecular reference altitude(s), except for the plume of 12 May where the lower molecular reference zone is very small 


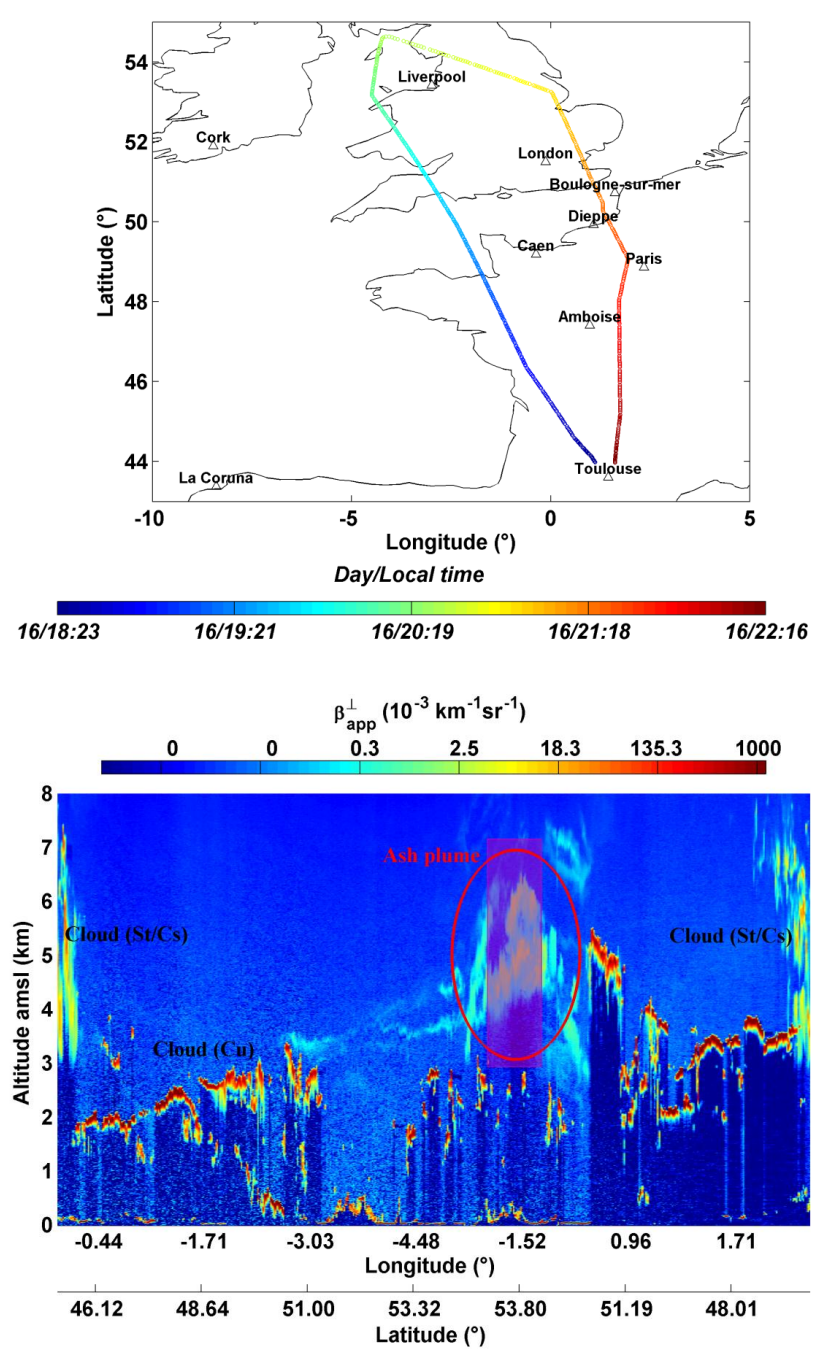

Fig. 6. The same as Fig. 4 for 16 May 2010, above UK.

$(\sim 150 \mathrm{~m})$ and for which the gap can be more important $(R=1.09)$.

\subsubsection{Aerosol optical thickness in the plume}

The AOTs at $355 \mathrm{~nm}$ retrieved from Eq. (8) for each case are given in Table 2. The calculation has been made between $z_{\mathrm{b}}$ and $z_{\mathrm{a}}$. The event on 16 May is the most intense with $\mathrm{AOT}=0.34$ compared with the ash plumes observed on 12 May with AOT of 0.19, 0.08 and 0.17 for the plume, plumecrown and filament, respectively.

For $R=1.05$, the bias $\left(\delta_{\mathrm{AOT}} \sim-0.02\right)$ on the AOT is the same whatever the AOT values. The bias is more than twice as important as for $R=1.09$ (between 0.04 and 0.05). The statistical uncertainty $\left(\varepsilon_{\text {АOT }}\right)$ linked to the signal noise is low (less than $4 \%$, Table 2). The error budget on the AOT leads to an absolute error $\Delta_{\text {AOT }}$ between 0.02 and 0.04 (Table 4).

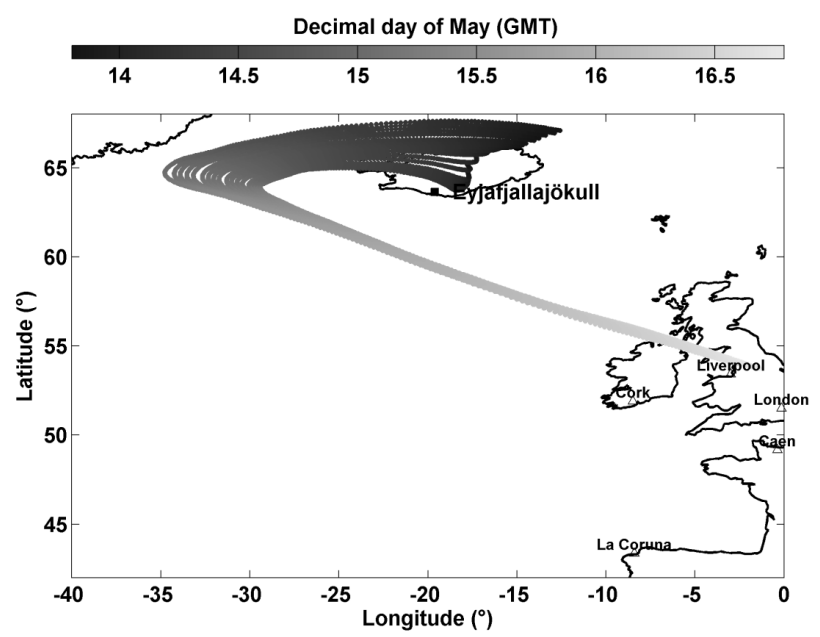

Fig. 7. The same as Fig. 6 for 16 May 2010.

\subsubsection{Aerosol extinction coefficient profiles}

Given the AOT of the ash plumes, the AL measurements on 12 and 16 May were converted into extinction coefficients using both the Klett (1985) backward algorithm and the dichotomy approach presented in Chazette (2003) or Royer et al. (2010). The mean vertical profiles of aerosol extinction coefficient are given in Fig. 9. The vertical structure can be complex as on 12 May with several maxima above $0.1 \mathrm{~km}^{-1}$. The maximum extinction coefficient in the vertical profile is given in Table 2 for each mean profile. The values are between 0.15 and $0.44 \mathrm{~km}^{-1}$ for the plume-crown and the filament of 12 May, respectively. The ash plume of 16 May has a maximum $\alpha_{\mathrm{a}}$ of $0.28 \mathrm{~km}^{-1}$. The statistic uncertainty $\varepsilon_{\alpha}$ and the absolute value of the bias $\delta_{\alpha}(R=1.05)$ are lower than 6 and $24 \%$, respectively (Tables 2 and 3). The relative error $\Delta_{\alpha}$ is $7 \%$ for the 16 May and between 10 and $25 \%$ for the 12 May (Table 4).

\subsubsection{Backscatter-to-Extinction Ratio in the plume}

The BER retrieved from AL measurements are also given in Table 2. It has been assumed to be constant in the ash layer for each mean vertical profile. The values between 0.020 and $0.023 \mathrm{sr}^{-1}$ (LR between 43 and $50 \mathrm{sr}$ ) are very close to those measured with ground-based Raman lidar near Paris with $0.021 \mathrm{sr}^{-1}$ (LR $\sim 48 \mathrm{sr}$, Royer et al., 2010) except for the filament $\left(\mathrm{BER}=0.027 \mathrm{sr}^{-1}\right.$ or $\left.\mathrm{LR}=37 \mathrm{sr}\right)$. This may be due to the presence of ice-nuclei within the ash filament as observed from airborne in situ measurements over UK by Schumann et al. (2011). Unfortunately, this last point is difficult to verify during our flights.

The LR in the ash plume retrieved in this study is close to the LR values of $50 \pm 5$ assessed by Ansmann et al. (2010) for Munich. The same authors measured $L R=60 \pm 5 \mathrm{sr}$ at Leipzig, which is larger than our values. The statistic error 

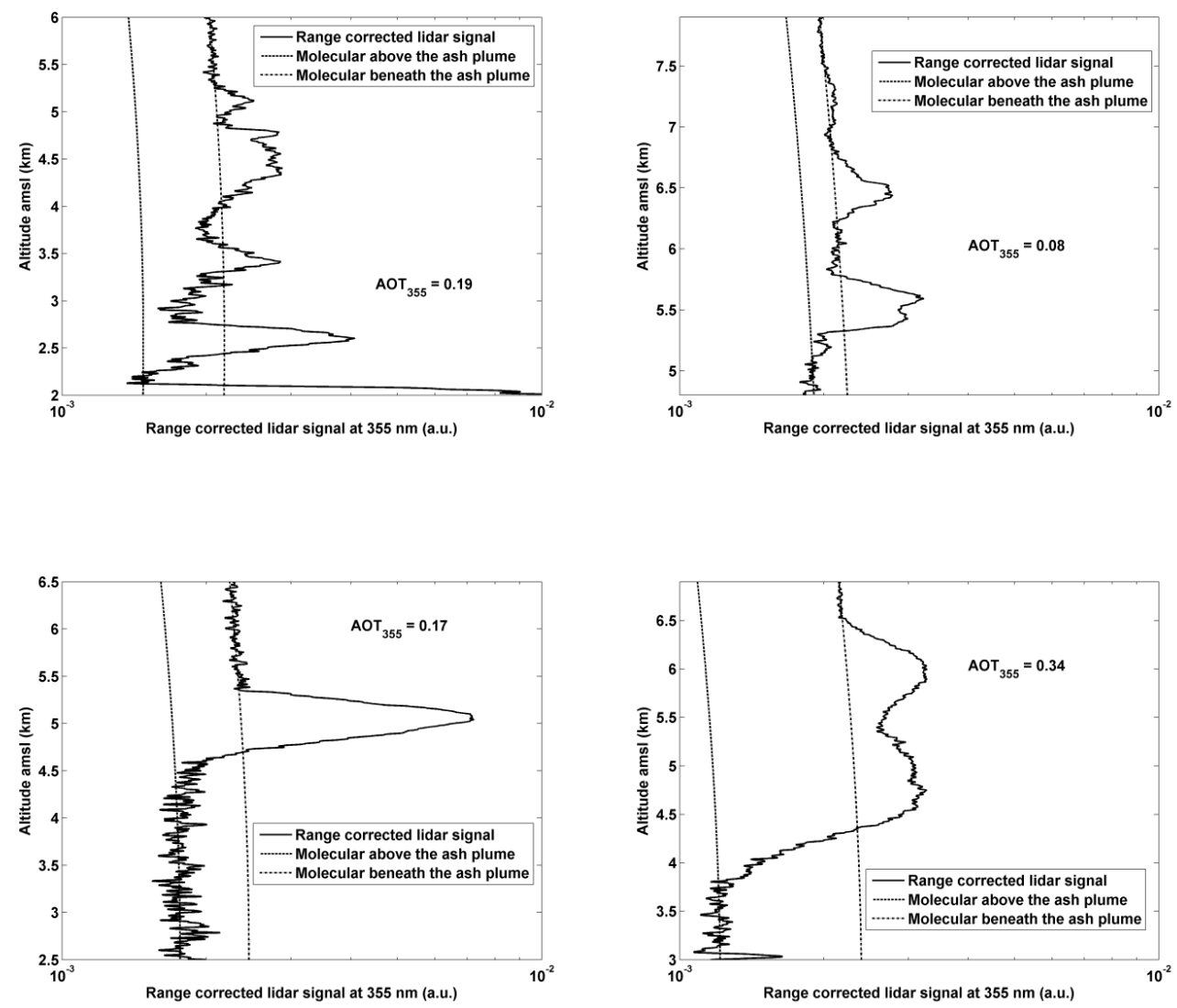

Fig. 8. Range-corrected lidar signal on 12 and 16 May 2010: top-left panel for the plume of 12 May $\left(-19.545^{\circ} \mathrm{E} 44.849^{\circ} \mathrm{N}, 16: 27\right.$ GMT), top-right panel for the plume crown of 12 May $\left(-18.532^{\circ} \mathrm{E} 44.860^{\circ} \mathrm{N}, 16: 15 \mathrm{GMT}\right)$, bottom-left panel for the filament of $12 \mathrm{May}$ $\left(-11.098^{\circ} \mathrm{E} 43.851^{\circ} \mathrm{N}, 15: 30 \mathrm{GMT}\right)$, and bottom-right panel for the plume of 16 May $\left(-1.706^{\circ} \mathrm{E} 53.858^{\circ} \mathrm{N}, 18: 42 \mathrm{GMT}\right)$. The molecular contributions have been simulated for each normalization altitude, and are also given in each figure.

$\left(\varepsilon_{\mathrm{BER}}\right)$ on the BER is low, between 2 and $5 \%$ due to the signal noise and between 2 and $3 \%$ due to the characterization of the Brewster plate transmissions. Nevertheless, the bias ( $\left.\delta_{\mathrm{BER}}\right)$ linked to $R=1.05$ may significantly overestimate the BER by $26 \%$ for the lower AOT of 0.08 (Table 3 ). Note that a value of $R=1.09$ significantly increases the bias on each parameters as shown Table 3. The total relative error $\Delta_{\mathrm{BER}}$ on BER is between 8 and $27 \%$ for 16 and 12 May, respectively (Table 4).

\subsubsection{Depolarization measurements}

The last optical parameter that we estimated is the PDR (Eq. 11) derived from the VDR (Eq. 3). Figure 10 gives the mean vertical profiles of both the VDR and the PDR when there is enough SNR. Marenco and Hogan (2011) performed ground-based elastic-backscattering lidar measurements at Exeter, United Kingdom, on 16 and 18 April 2010. They found VDR between 10 and $20 \%$ in agreement with the value shown Fig. 10. We have found mean values between 9 and $16 \%$ (Table 2). When working at the wavelength of $355 \mathrm{~nm}$ where molecular scattering is high, the most rep- resentative depolarization ratio is the PDR. Looking at the PDR profiles, we can see that the mean value is very stable, between $34 \pm 3 \%$ and $38 \pm 3 \%$ (Table 2). These values are within the range derived by Chazette et al. (2012) from GBL measurements. They are similar with those of Ansmann et al. (2011) or Gasteiger et al. (2011) who retrieved mean PDR at the same wavelength of $35-40 \%$ and $35.5 \pm 4.4 \%$, respectively. The ash plumes may evolve during transport by particle settling and their optical properties may be affected. Note that for the ash plume observed during the flights in May, the time needed to reach the measurement point after emission in the atmosphere was less than 3 days (Figs. 5 and 7) and the plume composition could be different from April including more or less sulfate aerosols. Sulfate particles modify the optical properties of the ash plumes, but this is something that we cannot verify during ours flights at $\sim 10 \mathrm{~km}$ a.m.s.l. Moreover, the ash plume is very heterogeneous and the ash properties could be different from an eruption to another. This may explain that the ash optical properties are not necessarily the same from a location to another, and from a date to another. It is also important to note that the uncertainties 
Table 3. Relative bias $\left(\delta_{x}\right)$ linked to the presence of aerosol at the two altitudes of normalization $z_{\mathrm{a}}$ and $z_{\mathrm{b}}$. When aerosols are present, the scattering ratio $R$ is higher than 1 . The gray areas are for assessments with $R\left(z_{\mathrm{b}}\right)=1.09$, which are not took into account in the error budget. The values in bold are those considered in the global error budget.

\begin{tabular}{|c|c|c|c|c|c|}
\hline & & $16 / 05$ & 12/05 Plume & 12/05 Plume-crown & 12/05 Filament \\
\hline $\begin{array}{l}R\left(z_{\mathrm{a}}\right)=1 \\
R\left(z_{\mathrm{b}}\right)=1.05\end{array}$ & $\begin{array}{l}\delta_{\mathrm{AOT}} \\
\delta_{\mathrm{BER}} \\
\delta_{\mathrm{PDR}} \\
\delta_{\alpha}\end{array}$ & $\begin{array}{r}7 \% \\
-2 \% \\
-3 \% \\
6 \%\end{array}$ & $\begin{array}{r}13 \% \\
-5 \% \\
-5 \% \\
9 \%\end{array}$ & $\begin{array}{r}31 \% \\
-26 \% \\
-4 \% \\
24 \%\end{array}$ & $\begin{array}{r}15 \% \\
-10 \% \\
-10 \% \\
-10 \%\end{array}$ \\
\hline $\begin{array}{l}R\left(z_{\mathrm{a}}\right)=1 \\
R\left(z_{\mathrm{b}}\right)=1.09\end{array}$ & $\begin{array}{l}\delta_{\mathrm{AOT}} \\
\delta_{\mathrm{BER}} \\
\delta_{\mathrm{PDR}} \\
\delta_{\alpha}\end{array}$ & $\begin{array}{r}12 \% \\
-4 \% \\
-5 \% \\
10 \%\end{array}$ & $\begin{array}{r}\mathbf{2 2} \% \\
-10 \% \\
-10 \% \\
17 \%\end{array}$ & $\begin{array}{r}53 \% \\
-66 \% \\
-9 \% \\
45 \%\end{array}$ & $\begin{array}{r}26 \% \\
-20 \% \\
-33 \% \\
20 \%\end{array}$ \\
\hline $\begin{array}{l}R\left(z_{\mathrm{a}}\right)=1.02 \\
R\left(z_{\mathrm{b}}\right)=1\end{array}$ & $\begin{array}{l}\delta_{\mathrm{AOT}} \\
\delta_{\mathrm{BER}} \\
\delta_{\mathrm{PDR}} \\
\delta_{\alpha}\end{array}$ & $\begin{array}{r}-3 \% \\
7 \% \\
-5 \% \\
-6 \%\end{array}$ & $\begin{array}{r}-4 \% \\
19 \% \\
-5 \% \\
-18 \%\end{array}$ & $\begin{array}{r}-12 \% \\
17 \% \\
-3 \% \\
-18 \%\end{array}$ & $\begin{array}{r}-5 \% \\
8 \% \\
-1 \% \\
-7 \%\end{array}$ \\
\hline $\begin{array}{l}R\left(z_{\mathrm{a}}\right)=1.02 \\
R\left(z_{\mathrm{b}}\right)=1.05\end{array}$ & $\begin{array}{l}\delta_{\mathrm{AOT}} \\
\delta_{\mathrm{BER}} \\
\delta_{\mathrm{PDR}} \\
\delta_{\alpha}\end{array}$ & $\begin{array}{r}4 \% \\
5 \% \\
-8 \% \\
1 \%\end{array}$ & $\begin{array}{r}8 \% \\
15 \% \\
-10 \% \\
-9 \%\end{array}$ & $\begin{array}{r}16 \% \\
2 \% \\
-9 \% \\
5 \%\end{array}$ & $\begin{array}{r}9 \% \\
1 \% \\
-10 \% \\
3 \%\end{array}$ \\
\hline $\begin{array}{l}R\left(z_{\mathrm{a}}\right)=1.02 \\
R\left(z_{\mathrm{b}}\right)=1.09\end{array}$ & $\begin{array}{l}\delta_{\mathrm{AOT}} \\
\delta_{\mathrm{BER}} \\
\delta_{\mathrm{PDR}} \\
\delta_{\alpha}\end{array}$ & $\begin{array}{r}9 \% \\
3 \% \\
-10 \% \\
5 \%\end{array}$ & $\begin{array}{r}17 \% \\
12 \% \\
-\mathbf{1 5 \%} \\
-1 \%\end{array}$ & $\begin{array}{r}39 \% \\
-21 \% \\
-15 \% \\
27 \%\end{array}$ & $\begin{array}{r}20 \% \\
-8 \% \\
-29 \% \\
12 \%\end{array}$ \\
\hline
\end{tabular}

Table 4. Total relative error on the ash optical parameters. The uncertainties have been considered to be independent. The ranges of the ash mass concentration (AMC) and ash mass integrated concentration (AMIC) are also given accounting for the previous errors. The relative uncertainties on AMC and AMIC are the same as $\max \left(\alpha_{\mathrm{a}}\right)$ and AOT, respectively.

\begin{tabular}{llrrrr}
\hline & & $16 / 05$ & $12 / 05$ Plume & $12 / 05$ Plume-crown & $12 / 05$ Filament \\
\hline & $\Delta_{R c}$ & $9 \%$ & $6 \%$ & $12 \%$ & $9 \%$ \\
& $\Delta_{\text {VDR }}$ & $8 \%$ & $6 \%$ & $10 \%$ & $9 \%$ \\
& $\Delta_{\text {AOT }}$ & $7 \%$ & $22 \%$ & $31 \%$ & $15 \%$ \\
Total relative error & $\Delta_{\text {BER }}$ & $8 \%$ & $19 \%$ & $27 \%$ & $10 \%$ \\
& $\Delta_{\text {PDR }}$ & $12 \%$ & $18 \%$ & $26 \%$ & $16 \%$ \\
& $\Delta_{\alpha}$ & $7 \%$ & $18 \%$ & $25 \%$ & $10 \%$ \\
\hline Range of AMC $\left(\mu \mathrm{g} \mathrm{m}^{-3}\right)$ & From max $\left(\alpha_{\mathrm{a}}\right)$ & 250 to 1500 & 370 to 2160 & 140 to 790 & 400 to 2300 \\
\hline Range of AMIC $\left(\mathrm{mg} \mathrm{m}^{-2}\right)$ & From AOT & 310 to 1800 & 170 to 1000 & 70 to 420 & 145 to 840 \\
\hline
\end{tabular}

on $T_{1,2}^{/ /}$may significantly affect VDR (6 to $\left.10 \%\right)$ and PDR (9 to $24 \%$ ) as shown Table 2 . The molecular scattering assumption in the reference altitudes $z_{\mathrm{a}}$ and $z_{\mathrm{b}}$ is also important and may lead to an underestimation of PDR by $15 \%$ (Table 3 ). Hence, the relative error $\Delta_{\mathrm{PDR}}$ on PDR is between $\sim 12(16$ May) and $\sim 26 \%$.

\subsection{Ash mass concentration}

A mass concentration estimate is a major requirement for aviation and for modeling purposes (e.g. Stohl et al., 2011). Nevertheless, no measurement of the ash microphysical properties was performed by the F-20 because the flights were dedicated to the ash plume tracking by the AL. Therefore we use the specific cross section $\left(\sigma_{\mathrm{s}}\right)$ of ash assessed from the previous literature on the Eyjafjallajökull volcano. Table 5 summarizes these values, which are widely dispersed, between 0.19 and $1.5 \mathrm{~m}^{2} \mathrm{~g}^{-1}$. The higher values are from Hogan et al. (2012), Gasteiger et al. (2011) and Johnson et al. (2011), and are between 1 and $1.5 \mathrm{~m}^{2} \mathrm{~g}^{-1}, 0.43$ and $1.15 \mathrm{~m}^{2} \mathrm{~g}^{-1}$, and 0.45 and $1.06 \mathrm{~m}^{2} \mathrm{~g}^{-1}$, respectively. Note that $\sigma_{\mathrm{s}}$ is close to $1.1 \mathrm{~m}^{2} \mathrm{~g}^{-1}$ for dust particles originating from Sahara (e.g. Raut and Chazette, 2009), hence $\sigma_{\mathrm{s}}$ for 
Table 5. Specific cross-section $\left(\sigma_{\mathrm{S}}\right)$ given in the literature.

\begin{tabular}{llll}
\hline Reference & $\sigma_{\mathrm{s}}\left(\mathrm{m}^{2} \mathrm{~g}^{-1}\right)$ & Wavelength $(\mathrm{nm})$ & Location and period of measurements \\
\hline Ansmann et al. (2010) & 0.43 & 355 and 532 & Leipzig and Munich, Germany April 2010 \\
Gasteiger et al. (2011) & $0.43-1.15$ & 532 & Munich, Germany April 2010 \\
Ansmann et al. (2011) & 0.66 & 532 & Central Europe April and May 2010 \\
Hogan et al. (2012) & $1.25 \pm 0.25$ & $340,355,1020$ and 1500 & UK April 2010 \\
Johnson et al. (2011) & $0.45-1.06$ & $355-680$ & UK April and May 2010 \\
Chazette et al. (2011) & $0.19 \pm 0.03-0.29 \pm 0.04$ & 355 & Paris, France April 2010 \\
\hline
\end{tabular}
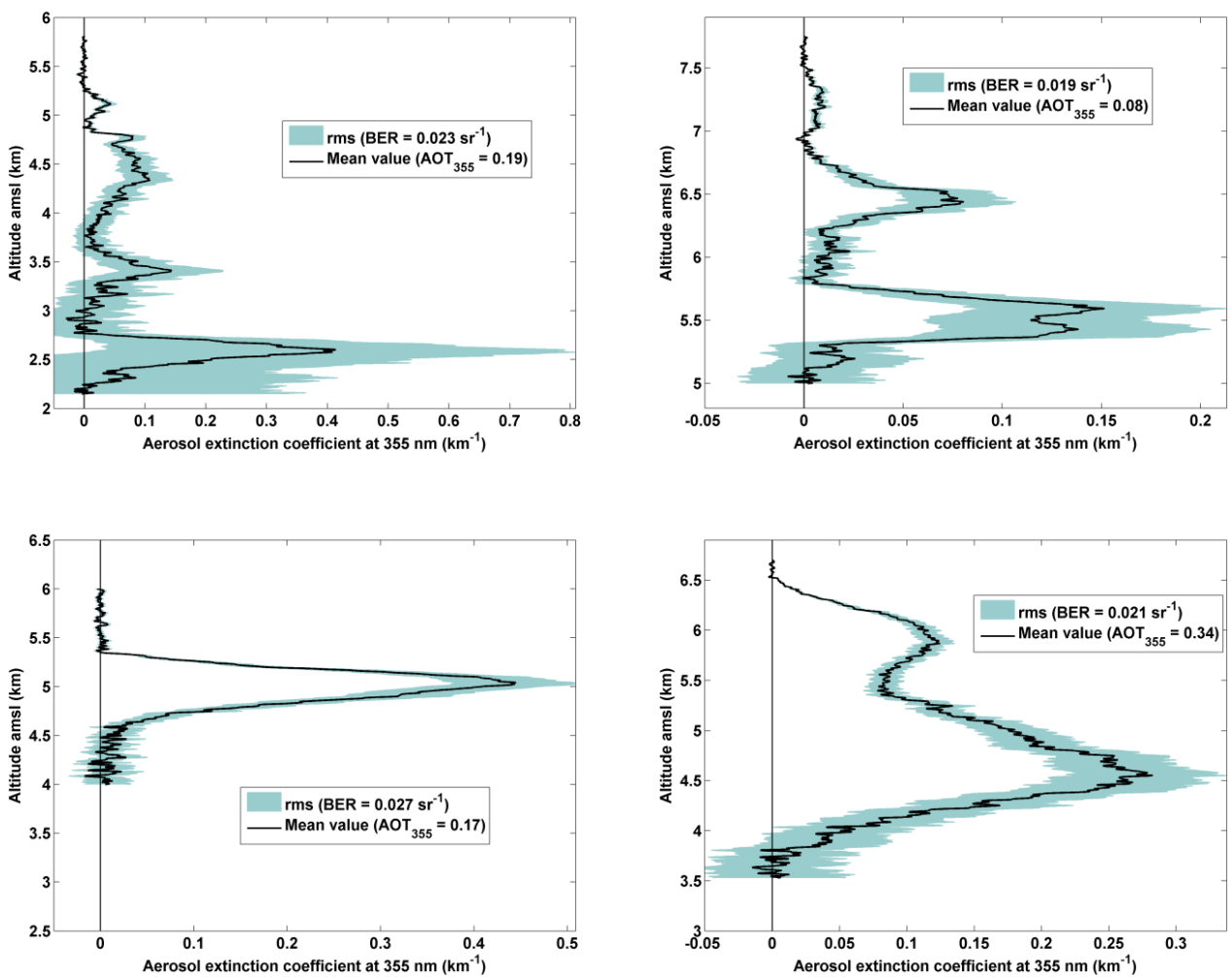

Fig. 9. Mean profiles of the aerosol extinction coefficient on 12 and 16 May 2010: top-left panel for the plume of 12 May, top-right panel for the plume crown of 12 May, bottom-left panel for the filament of 12 May, and bottom-right panel for the plume of 16 May. The standard deviation (rms) linked to the retrieval uncertainty is also given by the turquoise-blue area. The BER used for the inversion are also indicated. Note that the dynamics of figures are different.

dust aerosol can be considered as the upper boundary for ash. The lower value is given by Chazette et al. (2012) for ash plume over the Paris area with $\sigma_{\mathrm{s}}=0.19-0.29 \mathrm{~m}^{2} \mathrm{~g}^{-1}$. As shown by the previous authors, these values leads to coherent comparison with the Eulerian model Polair3D transport model. Intermediate values are given by Ansmann et al. (2010) with $\sigma_{\mathrm{s}} \sim 0.43 \mathrm{~m}^{2} \mathrm{~g}^{-1}$, and Ansmann et al. (2011) with $\sigma_{\mathrm{s}} \sim 0.66 \mathrm{~m}^{2} \mathrm{~g}^{-1}$ from the coupling between sunphotometer and a GBL.

Using the specific cross-sections between 0.19 and $1.1 \mathrm{~m}^{2} \mathrm{~g}^{-1}$ in the equation

$\mathrm{AMC}=\frac{\max \left(\alpha_{\mathrm{a}}\right)}{\sigma_{\mathrm{s}}}$ and $\mathrm{AMIC}=\frac{\mathrm{AOT}}{\sigma_{\mathrm{s}}}$, we assessed both the ash mass concentrations (AMC) corresponding to the maximum of $\alpha_{\mathrm{a}}$ and the ash mass integrated concentration (AMIC) across the plumes. The values are reported in Table 4. For each boundary of the AMC and AMIC, the relative uncertainties are the same as $\max \left(\alpha_{\mathrm{a}}\right)$ and AOT, respectively. For 12 May, the AMC (AMIC) is estimated between 140 and $2160 \mu \mathrm{g} \mathrm{m}^{-3}\left(70\right.$ and $1000 \mathrm{mg} \mathrm{m}^{-2}$ ) in the plume, and between 400 and $2300 \mu \mathrm{g} \mathrm{m}^{-3}$ (145 and $840 \mathrm{mg} \mathrm{m}^{-2}$ ) in the filament. Similar values are retrieved for 16 May with an AMC between 250 and $1500 \mu \mathrm{g} \mathrm{m}^{-3}$, and an AMIC between 310 and $1800 \mathrm{mg} \mathrm{m}^{-2}$.

For 16 May, the ash were injected in the troposphere between the 13 and 14 May (Fig. 7) and this plume has been 

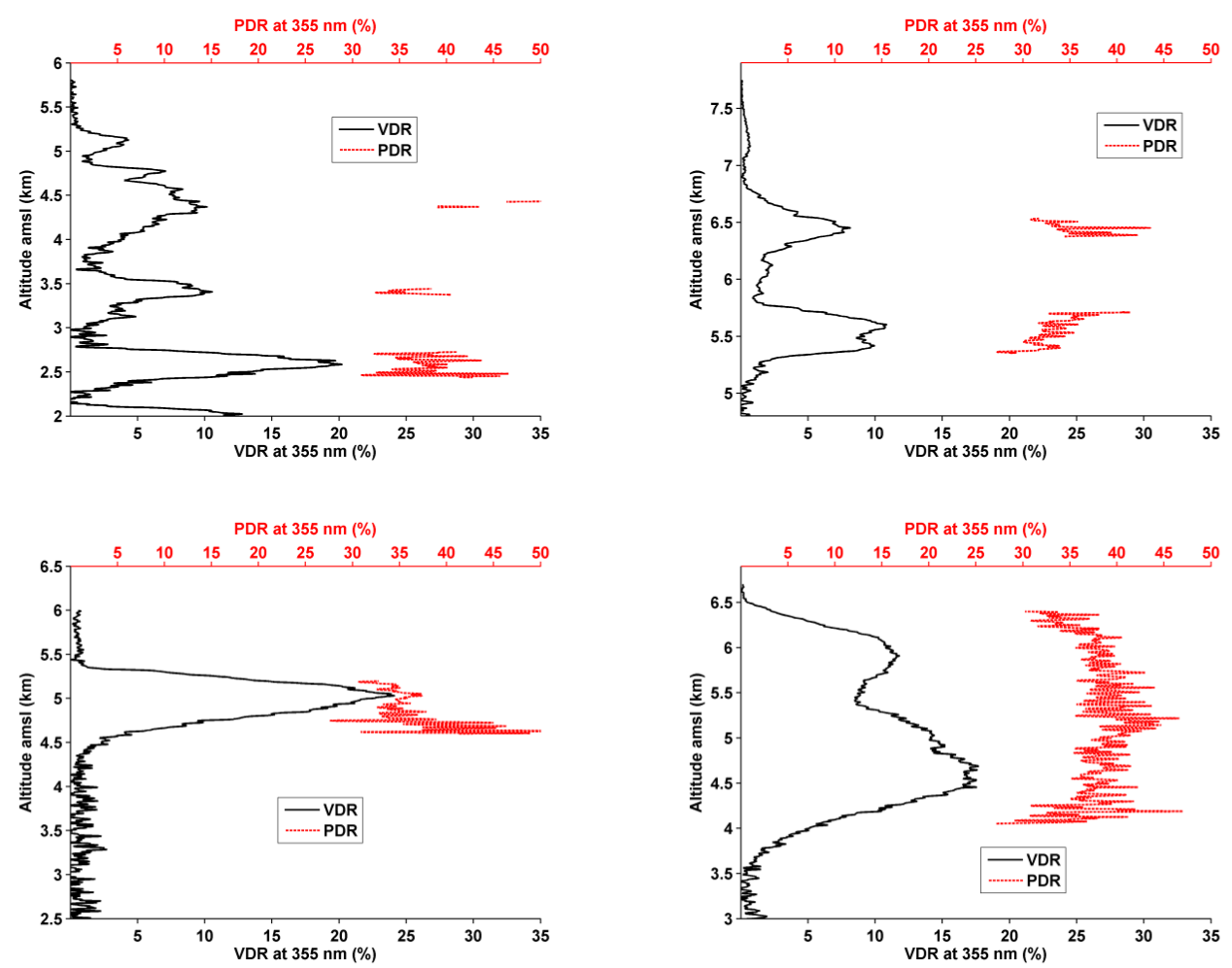

Fig. 10. Mean profiles of both the VDR and the PDR on 12 and 16 May 2010: top-left panel for the plume of 12 May, top-right panel for the plume crown of 12 May, bottom-left panel for the filament of 12 May, and bottom-right panel for the plume of 16 May.

sampled and modeled by Marenco et al. (2011). They found AMC (AMIC) $1000 \mu \mathrm{g} \mathrm{m}^{-3}\left(800 \mathrm{mg} \mathrm{m}^{-2}\right.$ ) with a typical value of $300 \mathrm{\mu g} \mathrm{m}^{-3}\left(250 \mathrm{mg} \mathrm{m}^{-2}\right)$ in the range of our results. We have no element of comparison for the 12 May.

\section{Conclusions}

Three operational flights were carried out with a RayleighMie lidar aboard the F-20 French research aircraft. The original purpose of these flights was to provide the French civil aviation authorities with objective information on the presence and location of ash plumes. The volcanic aerosol layers were identified mainly by using the perpendicular channel of the AL.

Ash plumes have been characterized by their PDR, which is very constant from a flight to another with value between 34 and $38 \%$. The detected ash plumes are very similar in term of optical properties except the ash filament observed on 12 May, which stayed longer in the atmosphere than the main plume. For the ash plumes, the backscatter ratio (lidar ratio) appears to be coherent with the previous finding with values between 0.020 to $0.023 \mathrm{sr}^{-1}$ (43 and $50 \mathrm{sr}$ ). The maximum AMC (between 140 and $2300 \mu \mathrm{g} \mathrm{m}^{-3}$ based on the likely range of the specific cross-section) may be rather less than or of the order of the critical level of damage given by the aircraft engine manufacturers $\left(2 \mathrm{mg} \mathrm{m}^{-3}\right)$ for the aircraft engines. Nevertheless, the $200 \mu \mathrm{g} \mathrm{m}^{-3}$ warning level was significantly reached.

The AL is thus utterly suitable for ash identification. Its measurements encompassed all the aerosol layers of the troposphere and are a powerful asset in the frame of a decision making tool. It supplied vertical profiles essential for the localization, the identification and the assessment of the ash content. In both April and May 2010, it enabled to confirm air traffic reopening over the French airspace. Nevertheless, a lidar alone is not sufficient for assessing the AMC with a good precision. First because the inversion is poorly constrained if no molecular scattering layer can be found beneath the ash plume. The inversion is then very unstable accounting for only a molecular reference above the plume. Second, ancillary data are needed for the assessment of the ash density and specific cross-section. The ideal condition is to use 2 aircrafts, one flying above the ash plume with a lidar and the second inside the plume. For the second aircraft, safety has to be taken into account. The modeling approach could be also a constraint, but model have to be initialized by local observations and/or satellites as Meteosat (SEVERI) or Aqua (MODIS). It is preferable to use a model computing the ash optical parameters to consider the lidar-derived optical properties as constraint. 
Acknowledgements. The SAFIRE team is greatly acknowledged for its effectiveness in the implementation of research aircraft and its support for the integration of lidar and its participation in the different flights. Xiao-Xia Shang, Fabien Marnas and Julien Totems are also greatly acknowledged for their help for characterizing the Brewster plates in laboratory. This work was supported by the Commissariat à l'Energie Atomique (CEA). The "Centre National d'Etudes Spatiales" (CNES), Météo-France and the "Institut des Sciences de l'Univers" (INSU) supported the achievement of the airborne experience.

\section{Edited by: G. Pappalardo}

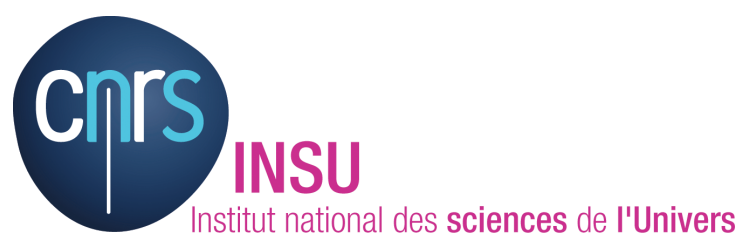

The publication of this article is financed by CNRS-INSU.

\section{References}

Ansmann, A., Tesche, M., Gross, S., Freudenthaler, V., Seifert, P., Hiebsch, A., Schmidt, J., Wandinger, U., Mattis, I., Muller, D., and Wiegner, M.: The 16 April 2010 major volcanic ash plume over central Europe: EARLINET lidar and AERONET photometer observations at Leipzig and Munich, Germany, Geophys. Res. Lett., 37, L13810, doi:10.1029/2010GL043809, 2010.

Ansmann, A., Tesche, M., Seifert, P., Groß, S., Freudenthaler, V., Apituley, A., Wilson, K. M., Serikov, I., Linné, H., Heinold, B., Hiebsch, A., Schnell, F., Schmidt, J., Mattis, I., Wandinger, U., and Wiegner, M.: Ash and fine-mode particle mass profiles from EARLINET- AERONET observations over central Europe after the eruptions of the Eyjafjallajökull volcano in 2010, J. Geophys. Res., 116, D00U02, doi:10.1029/2010JD015567, 2011.

Berthier, S., Chazette, P., Couvert, P., Pelon, J., Dulac, F., Thieuleux, F., Moulin, C., and Pain T.: Desert dust aerosol columnar properties over ocean and continental Africa from Lidar in-Space Technology Experiment (LITE) and Meteosat synergy, J. Geophys. Res., 111, D21202, doi:10.1029/2005JD006999, 2006.

Bukowiecki, N., Zieger, P., Weingartner, E., Jurányi, Z., Gysel, M., Neininger, B., Schneider, B., Hueglin, C., Ulrich, A., Wichser, A., Henne, S., Brunner, D., Kaegi, R., Schwikowski, M., Tobler, L., Wienhold, F. G., Engel, I., Buchmann, B., Peter, T., and Baltensperger, U.: Ground-based and airborne in-situ measurements of the Eyjafjallajökull volcanic aerosol plume in Switzerland in spring 2010, Atmos. Chem. Phys., 11, 10011-10030, doi:10.5194/acp-11-10011-2011, 2011.

Collis, R. T. H. and Russell, P. B.: Lidar measurement of particles and gases by elastic backscattering and differential absorption in Laser Monitoring of the Atmosphere, edited by: Hinkley, E. D., 71-152, Springer-Verlag, New York, 1976.

Chazette, P.: The monsoon aerosol extinction properties at Goa during INDOEX as measure with lidar, J. Geophys. Res., 108, 4187, doi:10.1029/2002JD002074, 2003.
Chazette, P., David, C., Lefrère, J., Godin, S., Pelon, J., and Mégie, G.: Comparative lidar study of the optical, geometrical, and dynamical properties of stratospheric post-volcanic aerosols, following the eruption of El Chichon and Mount Pinatubo, J. Geophys. Res., 100, 23195-23207, 1995.

Chazette P., Pelon, J., and Mégie, G.: Determination of structural parameters of atmospheric scattering layer using spaceborne backscatter lidar, Appl. Opt., 40, 3428-3440, 2001.

Chazette, P., Sanak., J., and Dulac, F.: New Approach for Aerosol Profiling with a Lidar Onboard an Ultralight Aircraft: Application to the African Monsoon Multidisciplinary Analysis, Environ. Sci. Technol., 41, 8335-8341, 2007.

Chazette, P., Bocquet, M., Royer, P., Winiarek, V., Raut, J.-C., Labazuy, P., Gouhier, M., Lardier, M., and Cariou, J.-P.: Eyjafjallajökull ash concentrations derived from both lidar and modeling, J. Geophys. Res., 117, D00U14, doi:10.1029/2011JD015755, 2012.

Collis, R. T. H. and Russell, P. B.: Lidar measurement of particles and gases by elastic backscattering and differential absorption in Laser Monitoring of the Atmosphere, edited by: Hinkley, E. D., 71-152, Springer-Verlag, New York, 1976.

Gasteiger, J., Groß, S., Freudenthaler, V., and Wiegner, M.: Volcanic ash from Iceland over Munich: mass concentration retrieved from ground-based remote sensing measurements, Atmos. Chem. Phys., 11, 2209-2223, doi:10.5194/acp-11-22092011, 2011.

Gertisser, R.: Eyjafjallajökull volcano causes widespread disruption to European air traffic, Geol. Today, 26, 94-95, 2010.

Hogan, R. J., Haywood, J. M., Westbrook, C. D., Dacre, H. F., Marenco, F., O'Connor, E. J., Johnson, B. T., Wrench, C. L., and Belcher, S. E.: Combined lidar and sunphotometer retrievals of ash particle size and mass concentration from the Eyjafjallajökull volcano, J. Geophys. Res., in press, 2012.

Jäger, H.: The Pinatubo eruption cloud observed by lidar at Garmisch-Partenkirchen, Geophys. Res. Lett., 19, 191-194, 1992.

Johnson, B., Turnbull, K., Dorsey, J., Baran, A. J., Ulanowski, Z., Hesse, E., Cotton, R., Brown, P. R. A., Burgess, R., Capes, G., Webster, H., Woolley, A., Rosenberg, P., and Haywood, J. M.: In situ observations of volcanic ash clouds from the FAAM aircraft during the eruption of Eyjafjallajökull in 2010, J. Geophys. Res., 117, D00U24, doi:10.1029/2011JD016760, 2011.

King, L. V.: On the complex anisotropic molecule in relation to the dispersion and scattering of light, Proceedings of the Royal Society of London, Series 1, 104, 333-357, 1923.

Klett, J. D.: Lidar inversion with variable backscatter/extinction ratios, Appl. Optics, 24, 1638-1643, 1985.

Marenco, F. and Hogan, R.: Determining the contribution of volcanic ash and boundary-layer aerosol in backscatter lidar returns: A three-component atmosphere approach, J. Geophys. Res., 116, D00U06, doi:10.1029/2010JD015415, 2011.

Marenco, F., Johnson, B., Turnbull, K., Newman, S., Haywood, J., Webster, H., and Ricketts, H.: Airborne lidar observations of the 2010 Eyjafjallajökull volcanic ash plume, J. Geophys. Res., 116, D00U05, doi:10.1029/2011JD016396, 2011.

Mattis, I., Siefert, P., Müller, D., Tesche, M., Hiebsch, A., Kanitz, T., Schmidt, J., Finger, F., Wandinger, U., and Ansmann, A.: Volcanic aerosol layers observed with multiwavelength Raman lidar over central Europe in 2008-2009, J. Geophys. Res., 115, 
D00L04, doi:10.1029/2009JD013472, 2010.

Measures, R. M.: Laser remote sensing: Fundamentals and Applications, Wiley \& Sons, New York, 1994.

Millington, S. C., Saunders, R., Francis, P., and Webster, H. N.: Simulated volcanic ash imagery: A method to compare NAME ash concentration forecasts with SEVIRI imagery for the Eyjafjallajökull eruption in 2010, J. Geophys. Res., 117, D00U17, doi:10.1029/2011JD016770, 2012.

Nicolet, M.: On the molecular scattering in the terrestrial atmosphere, Planet. Space Sci., 32, 1467-1468, doi:10.1016/00320633(84)90089-8, 1984.

Osborn, M. T., Winker, D. M., Woods, D. C., DeCoursey, R. J., and Trepte, C. R.: Evolution of the Pinatubo volcanic cloud over Hampton, Virginia, Geophys. Res. Lett., 22, 1101-1104, 1995.

Pappalardo, G., Amodeo, A., Mona, L., Pandolfi, M., Pergola, N., and Cuomo, V.: Raman lidar observation of aerosol emitted during the 2002 Etna eruption, Geophys. Res. Lett., 31, L05120, doi:10.1029/2003GL019073, 2004.

Prata, A. J., Gangale, G., Clarisse, L., and Karagulian, F.: Ash and sulfur dioxide in the 2008 eruptions of Okmok and Kasatochi: Insights from high spectral resolution satellite measurements, J. Geophys. Res., 115, D00L18, doi:10.1029/2009JD013556, 2010.

Raut, J.-C. and Chazette, P.: Assessment of vertically-resolved $\mathrm{PM}_{10}$ from mobile lidar observations, Atmos. Chem. Phys., 9, 8617-8638, doi:10.5194/acp-9-8617-2009, 2009.

Rosen, J. M. and Hofmann, D. J.: Optical modeling of stratospheric aerosols: present status, Appl. Opt., 25, 410-419, 1986.

Royer, P., Chazette, P., Lardier, M., and Sauvage, L.: Aerosol content survey by mini-N2-Raman lidar: Application to local and long-range transport aerosols, Atmos. Environ., 45, 7487-7495, doi:10.1016/j.atmosenv.2010.11.001, 2011.

Sassen, K., Zhu, J., Webley, P., Dean, K., and Cobb, P.: Volcanic ash plume identification using polarization lidar: Augustine eruption, Alaska, Geophys. Res. Lett., 34, L08803, doi:10.1029/2006GL027237, 2007.
Schumann, U., Weinzierl, B., Reitebuch, O., Schlager, H., Minikin, A., Forster, C., Baumann, R., Sailer, T., Graf, K., Mannstein, H., Voigt, C., Rahm, S., Simmet, R., Scheibe, M., Lichtenstern, M., Stock, P., Rüba, H., Schäuble, D., Tafferner, A., Rautenhaus, M., Gerz, T., Ziereis, H., Krautstrunk, M., Mallaun, C., Gayet, J.F., Lieke, K., Kandler, K., Ebert, M., Weinbruch, S., Stohl, A., Gasteiger, J., Groß, S., Freudenthaler, V., Wiegner, M., Ansmann, A., Tesche, M., Olafsson, H., and Sturm, K.: Airborne observations of the Eyjafjalla volcano ash cloud over Europe during air space closure in April and May 2010, Atmos. Chem. Phys., 11, 2245-2279, doi:10.5194/acp-11-2245-2011, 2011.

Sigmundsson, F., Hreinsdottir, S., Hooper, A., Arnadottir, T., Pedersen, R., Roberts, M. J., Oskarsson, N., Auriac, A., Decriem, J., Einarsson, P., Geirsson, H., Hensch, M., Ofeigsson, B. G., Sturkell, E., Sveinbjornsson, H., and Feigl, K. L.: Intrusion triggering of the 2010 Eyjafjallajökull explosive eruption, Nature, 468, 426-430, 2000.

Stohl, A., Prata, A. J., Eckhardt, S., Clarisse, L., Durant, A., Henne, S., Kristiansen, N. I., Minikin, A., Schumann, U., Seibert, P., Stebel, K., Thomas, H. E., Thorsteinsson, T., Tørseth, K., and Weinzierl, B.: Determination of time- and height-resolved volcanic ash emissions and their use for quantitative ash dispersion modeling: the 2010 Eyjafjallajökull eruption, Atmos. Chem. Phys., 11, 4333-4351, doi:10.5194/acp-11-4333-2011, 2011.

Thomas, H. E. and Watson, I. M.: Observations of volcanic emissions from space: Current and future perspectives, Nat. Hazards, 54, 323-354, 2010.

Wang, X., Boselli, A., D’Avino, L., Pisani, G., Spinelli, N., Amodeo, A., Chaikovsky, A., Wiegner, M., Nickovic, S., Papayannis, A., Perrone, M. R., Rizi, V., Sauvage, L., and Stohl, A.: Volcanic dust characterization by EARLINET during Etna's eruptions in 2001-2002, Atmos. Environ., 42, 893-905, 2008.

Winker, D. M. and Osborn, M. T.: Airborne Lidar Observations of the Pinatubo Volcanic Plume, Geophys. Res. Lett., 19, 167-170, 1992. 